\title{
Exposure as Collected End Date and Time of Treatment
}

National Cancer Institute

\section{Source}

National Cancer Institute. Exposure as Collected End Date and Time of Treatment. NCI

Thesaurus. Code C117497.

The date and time of the end of the exposure collection period. 